\title{
A FENNTARTHATÓ ÉRTÉKREND VIZSGÁLATA DEBRECENI EGYETEMISTÁK KÖRÉBEN
}

\author{
- भी० - \\ THE INVESTIGATION OF SUSTAINABLE VALUES AMONG \\ THE STUDENTS OF THE UNIVERSITY OF DEBRECEN \\ - \\ BALSA-BUDAI, Nikolett \\ SZAKÁLY, Zoltán
(a)
Debreceni Egyetem, Gazdaságtudományi Kar, Marketing és Kereskedelem Intézet (University of Debrecen, Faculty of Economics and Business, Institute of Marketing and Commerce) H-4032 Debrecen, Böszörményi út 138. e-mail: budai.nikolett93@gmail.com

\&

The aim of the research was to define sustainable values among the students of the University of Debrecen. We analysed the lifestyle of two sustainable consumption groups, the LOHAS (Lifestyle of Health and Sustainability) and the LOVOS (Lifestyle of Voluntary Simplifiers). As a first step, connection points were being looked for between the LOHAS and the LOVOS segments with the assistance of the literature review. Secondly, a questionnaire-based survey was carried out involving 298 students of the University of Debrecen. In this step appearance of sustainable values was analysed using factor analysis both for LOHAS and LOVOS segments separately. Next, we made a value-based lifestyle segmentation of the students with the assistance of hierarchical analysis in the case of the LOHAS segment and k-means analysis in the case of the LOVOS segment. According to the results, four value-based segments could be distinguished in both the LOHAS and the LOVOS groups. In the case of the LOHAS consumer group, the ambitious trend followers (the cluster size was $\mathbf{2 5 . 1 \%}$ of the asked students) reflect the characteristics of the LOHAS consumers' lifestyle to the greatest extent. In the case of the LOVOS consumer group, the most dedicated cluster was the conscious simplifiers (the cluster size was $34.55 \%$ of the asked students). However, this segment does not entirely reflect all the values of the LOVOS consumers' lifestyle, so further research is necessary in the future.

KuLCSSZAVAK: fenntartható fogyasztás, LOHAS, LOVOS, életstílus

JEL-KóDok (JEL CODES): A13, Q56, D70

DOI: https://doi.org/10.20494/TM/5/1/1

\section{BEVEZETÉS - INTRODUCTION}

Napjainkban a fogyasztási kultúra átalakulóban van, a fogyasztók számára új értékek kerülnek középpontba; a materializmust felváltja az élményközpontúság, az individualizmus mellett megjelenik a közösségbe való tartozás fontossága és a fogyasztók egyre inkább elfordulnak a túlfogyasztástól, miközben a hedo-
KEYWORDS: sustainable consumption, LOHAS, LOVOS, lifestyle

nizmusról sem kívánnak lemondani (MITEV és HORVÁTH, 2008; RÁCZ, 2013). Azonban nem csak értékrend változásról beszélhetünk, hanem az az út is átalakulóban van, amelyet a fogyasztóknak be kell járniuk az információszerzéshez és vásárláshoz. Ez pedig elsősorban a digitalizációnak köszönhető (FEHÉR, SOÓS és SZAKÁLY, 2014).

Induló hipotézisünk szerint a fenntartha- 
tóság előtérbe kerülése és a fogyasztók értékrendjének változása között összefüggés van (HOFMEISTER-TÓTH, 2016; TORDA, 2016; TÖRŐCSIK, 2016), amelynek feltárása volt a fó célunk a kutatásunk során. Több kutatás (RÁCZ, 2013; SZAKÁLY et al., 2015b; SZAKÁLY et al., 2017) bizonyítja, hogy hazánkban is megjelent a fenntartható fogyasztás iránt elkötelezettek csoportja (LOHAS - Lifestyle Of Health and Sustainability), akik a fenntarthatóság mindhárom - társadalmi, gazdasági és környezeti - szempontját figyelembe veszik fogyasztásuk során (SIMAI, 2016).

Szakály és szerzőtársai által 2015-ben elvégzett kutatásból kiderül, hogy a magyar lakosság 8,7\% tartozik a LOHAS fogyasztói csoportba, de méretük és gazdasági jelentőségük a jövőben várhatóan növekedni fog (SZAKÁLY, 2015b). A kutatás arra is rámutatott, hogy a LOHAS értékrendszerrel szemben az egyik legelkötelezettebb csoport a „Fiatal trendkövetők” szegmense, amelynek tagjai jellemzően 18-29 évesek, és felülreprezentáltak a felsőfokú végzettséggel rendelkezők (SZAKÁLY et al., 2015b).

Kutatásunk szükségességét alátámasztja, hogy a fenntartható értékrenddel kapcsolatosan, a fiatal korosztályt (18-29 éves, felsőfokú oktatásban résztvevő) vizsgáló kutatás hazánkban, tudomásunk szerint, még nem készült. A mintavételezés helyszíneként a Debreceni Egyetemet választottuk, mivel ez az egyetem az ország egyik legnagyobb hallgatói létszámmal rendelkező felsőoktatási intézménye, illetve ez a helyszín biztosította számunkra a legjobb lehetőséget a mintavételezésre.

A LOHAS szegmens mellett egy másik fenntarthatóság iránt elkötelezett fogyasztói csoport tulajdonságait is vizsgáltuk (LOVOS - Lifestyle Of Voluntary Simplifiers) az egyetemisták körében. A LOVOS szegmens vagy más néven önkéntes egyszerüsítők jellemzőire vonatkozó primer kutatásra, tudomásunk szerint, szintén nem került még sor hazánkban.

Az önkéntes egyszerüsítők, hasonlóan a LOHAS szegmens képviselőihez életstílusuk kialakításakor figyelembe veszik a fenntarthatóság mindhárom (környezeti, gazdasági és társadalmi) tényezőjét (ELGIN és MITCHELL, 1977; BALLANTINE és CREERY, 2009; RICH, HANNA és WRIGHT, 2017).
Kutatásunk célja a fenntartható értékrend elemzése a debreceni egyetemisták körében. Első lépésként feltártuk a LOHAS és LOVOS fogyasztói csoportok értékeit és vizsgáltuk a két szegmens közötti kapcsolatokat. Ezt követően faktoranalízissel elemeztük az értékek megjelenését debreceni egyetemisták körében, majd k-means és hiearchikus klaszterezési eljárást alkalmazva végeztük el az egyetemisták értékrendalapú életstílus-szegmentációját mindkét szegmens esetében külön-külön.

\section{A LOHAS És LOVOS FOGYASZTóK JELLEMzóI ÉS ÉRTÉKRENDJE - \\ CharaCteristics AND VALUES OF THE LOHAS AND LOVOS}

\section{CONSUMERS}

A szakirodalom alapján a fenntartható fogyasztás iránt legelkötelezettebb fogyasztói magatartást nevezzük LOHAS-nak, amely a szegmens elnevezésében is megjelenik - Lifestyle of Health and Sustainability (SZAKÁLY et al., 2015a). Az életstílust, a nemzetközi szakirodalmak alapján, elsősorban olyan középkorú nők képviselik, akik magas jövedelemmel és felsőfokú képzettséggel rendelkeznek.

A 2015. évi hazai, országos kutatás eredményei alapján a LOHAS fogyasztók az életkor tekintetében mutatnak leginkább eltérést a nemzetközi mintáktól. Hazánkban ugyanis jellemzően 10-15 évvel fiatalabb korosztály (1839 évesek) esetében jelentek meg az életstílus értékei, amely feltehetőleg annak köszönhető, hogy az értékorientáció-váltás ennyivel később következetett be hazánkban, mint a fejlett országokban (SZAKÁLY et al., 2015b). A szegmens tagjai a következő életstílusukat meghatározó alapértékekkel rendelkeznek: autentikus értékek, egészségtudatos értékek, etikus értékek, individualista értékek és környezettudatos értékek (RÁCZ, 2013).

Összességében elmondható, hogy az életstílus képviselőire jellemző a túlfogyasztástól való elfordulás, törekednek az egészség- és környezettudatos élet kialakítására, de megjelenik körükben a hagyomány, az autentikus és a humán értékek preferenciája is (SZAKÁLY et 
al., 2015a). Mindemellett helyt kap az individualizmus és a hedonizmus is, amely tényezők látszólag ellentmondásosak az előzőleg említett értékekkel, így a LOHAS szegmens tagjai egyfajta hibrid fogyasztói csoportot alkotnak.

$\mathrm{Az}$ individuum fontossága elsősorban a karrierorientáltságban és az egyedi, márkás termékek vásárlásának preferálásában jelenik meg. A szegmens tagjai életvitelük során a hedonizmusról sem kívánnak lemondani; az élménymaximalizálásra való törekvés, a wellness és a kényelem iránti igény szintén megjelenik az életstílus jellemzők között akárcsak a félkész, már előrecsomagolt termékek előnyben részesítése (SZAKÁLY et al., 2015a; SZAKÁLY et al., 2015b).

A hedonizmus és a látszólag egymásnak ellentmondó értékek képviselete miatt azonban a szakértők megkérdőjelezik, hogy a LOHAS életstílus tagjai valóban a fenntartható fogyasztást leginkább megvalósító fogyasztói csoportnak tekinthetőek-e. Emiatt szükségesnek találtuk kutatásunkat kiterjeszteni egy másik, a fenntartható fogyasztás iránt szintén elkötelezett szegmens vizsgálatára is.

Az önkéntes egyszerüsítők, vagy más néven LOVOS - Lifestyle Of Voluntary Simplifiers - szegmenst még az 1930-as évek során azonosították Amerikában (GREGG, 2003). Az életstílus képviselői - amire elnevezésük mozaik szó tartalma is utal - elsősorban egyszerü, fenntartható életmód kialakítására törekednek, ahol elfordulnak a materialista értékektől és az anyagi javak maximalizására való törekvéstől. Úgy gondolják ugyanis, hogy az anyagi javak túlzott hajszolása boldogtalanság kialakulásához vezet, így inkább a közösségi és spirituális értékeket helyezik a középpontba, mint amilyen a vallás is. Életvitelük során céljuk egy olyan életmód kialakítása, ahol fogyasztásukat a valódi szükségleteik szerint alakítják minőségi, környezetbarát javak vásárlásával. Szintén megjelenik náluk a humán értékek felértékelődése (pl. jótékonysági akciókban való részvétel, fair trade és állatkísérletektől mentes termékek vásárlása), illetve a természetesség, a természet közeliség keresése.

ELGIN és MITCHELL (1977), úgygondolták, hogy az életstíluscsoport tagjai értékeikből és elköteleződésükből adódóan olyan többdimenziós megmozdulást képesek véghez vinni, amely során a fogyasztási szokások, az intézményesítés, a politikai rendelkezések és a társadalom szerkezetének átalakulása is megváltozhat. Elmondásuk szerint az önkéntes egyszerüség lényege az egyszerü külsőségekben és a gazdag belső értékekben rejlik. Ez az életstílus magába foglalja a takarékos fogyasztást, a környezet védelmére való erős törekvést, az emberi léptékhez való visszatérést a természet előtérbe helyezésével. További célja az emberi lehetőségek felismerése, mind pszichológiai, mind spirituális értelemben véve, mindezt pedig együtt, közösségben végrehajtva.

Az életstílus kapcsán azonban fontos tisztázni, mit nem tekinthetünk önkéntes egyszerüsítésnek. ETZIONI (1999) a szegmens képviselőire vonatkozó definíciójában megjelenik az egyik legfontosabb tényező a szabad akarat kérdése. Olyan személyek, akik szabad akaratukból döntenek amellett, hogy kiadásaikat és fogyasztásukat csökkentik és helyettük inkább a nem-anyagi források és tényezők alakítják a fogyasztói elégedettségüket. Ez alapján a kényszerű fogyasztáscsökkentést, amelyet valamilyen külső körülmény, elsősorban a szegénység okoz, nem tekinthetjük az életstílus jellemzőjének. A szegmens tagjai továbbá nem törekednek a fogyasztásuk olyan mértékü csökkentésére, amely a testük sanyargatásával járna együtt. A szélsőségektől való elhatárolódás jelenik meg a technológiai fejlődés elutasításában is, az életstílus képviselői csak olyan fejlesztéseket támogatnak, amelyek összeegyeztethetők az értékrendjükkel és a fenntartható fejlődés alapelveivel (KOCSIS, 2001).

Összességében az önkéntes egyszerüsítők életstílusa olyan értékkategóriák köré szerveződik, mint az anyagi egyszerűség, az emberi lépték, az önállóság, az ökológiai tudatosság és a személyes gyarapodás (ELGIN és MITCHELL, 1977; KOCSIS, 2001).

\section{ANYAg ÉS MóDSZER - MATERIALS AND METHODS}

$\mathrm{Az}$ irodalmi áttekintést követően (KOCSIS, 2001; TÖRŐCSIK, 2007; RÁCZ, 2013; PEYER et al., 2017) meghatároztuk a LOHAS és a LOVOS fogyasztók legfontosabb értékeit. Ennek alapján elkészítettük azt az elméleti mo- 
dellt, amely a két fenntarthatóság irányában elkötelezett szegmens (LOHAS és LOVOS) közötti kapcsolatrendszert elemzi, meghatározva a legfontosabb kapcsolódási pontokat és különbségeket a csoportok között.

\subsection{Mintavétel - Sampling}

A kutatás célkitűzésének megvalósítására egy kérdőíves felmérést végeztünk debreceni egyetemisták körében. A megkérdezést 2017 áprilisában indítottuk el, amely során online (Google Drive ürlapszerkesztő program) és offline (papíralapú) mintavételi módszert egyaránt alkalmaztunk. A hibrid mintavételezési módszer mellett a minta megfelelő összetételének kialakítása érdekében döntöttünk. A mintavételi sokaságot 298 fó alkotta, a nemek szerinti megoszlás alapján a válaszadók 47,3\%a férfi, míg 52,7\%-a nő volt. A kutatás feltáró jellegü, így az eredmények nem tekinthetők reprezentatívnak.

\subsection{Kérdőív - Questionnaire}

A vizsgálat során alkalmazott kérdőívet több, már előzőleg elkészített állításlista alapján állítottuk össze (RÁCZ, 2013; FEHÉR, 2016), illetve saját állításokkal is kiegészítettük. A megkérdezés első részében a LOHAS szegmenst vizsgáltuk RÁCZ (2013) kérdőíve alapján, amelyből 24 változó került bevonásra a vizsgálat során. Az állítások, hasonlóan SZAKÁLY és munkatársai (2015a) megkérdezéséhez, 5 tényező mentén kerültek kialakításra (környezettudatos értékek, egészségtudatos értékek, etikus értékek, autentikus értékek és individualista értékek).

A kérdőív második kérdésblokkját a LOVOS szegmensre vonatkozó állítások alkották, az ide tartozó 7 tényezőt a szakirodalmak alapján határoztuk meg. A megkérdezés harmadik részében az online fogyasztók vásárlási magatartásának feltérképezése volt a célunk FEHÉR (2016) állításlistája alapján. Az állításlistából az a 10 tényező került be a kérdőívbe, amelyeket a vizsgálat szempontjából relevánsnak ítéltünk meg, azonban ezen vizsgálat eredményei jelenlegi tanulmányunkban nem kerülnek bemutatásra.

A megkérdezés során a kérdőív első két kérdésblokkjában a válaszadók egy ötfokozatú intervallum skála segítségével (1-egyáltalán nem, 5-teljes mértékben) értékelték az állításokat. A harmadik kérdésblokkban az egyes fogyasztási cikkek online vásárlási gyakoriságát mértük, szintén ötfokozatú intervallum skálát használva, ahol az egyes értékek a vásárlás gyakoriságát tükrözték (1-naponta, míg az 5-évente egyszer vagy kevesebbszer). A kérdőív utolsó szakaszába kerültek a szocio-demográfiai háttérváltozók (nem, lakóhely, családi állapot, a háztartás elsődleges élelmiszer-beszerzője és az internetezéssel eltöltött idő). Mivel a megkérdezés debreceni egyetemisták körében zajlott, ezért az iskolai végzettség és az életkor eleve homogén volt, így ezek a háttérváltozók nem kerültek külön vizsgálatra a kutatás során. A szocio-demográfiai háttérváltozók megoszlását az 1. táblázat foglalja össze.

\subsection{Adatelemzés - Statistical Analysis}

A kérdőívek feldolgozása matematikai-statisztikai elemző szoftverrel (SPSS 23.0) történt. Az adatfeldolgozás során a leíró statisztikák mellett kereszttábla-, faktor- és klaszterelemzést is alkalmaztunk (LÁZÁR, 2009).

Az elemzés első lépéseként az egyes változók közötti kapcsolatrendszer feltárása érdekében (SAJTOS és MITEV, 2007) külön-külön elvégeztük a faktoranalízist fókomponens elemzéssel (Varimax módszert használva, Kaiser-féle normalizációval) a LOHAS és LOVOS szegmensre vonatkozó állításoknál egyaránt (FIELD, 2013). Az egyes tényezőcsoportok megbízhatósági vizsgálatához Cronbach alfa értékeket számítottunk, amely számítást mind a LOVOS, mind a LOHAS szegmensre vonatkozóan elvégeztük (GLIEM, 2003).

Ezt követően megvizsgáltuk, hogy az egyes változók mennyire alkalmasak a faktorelemzésre, amelyhez KMO-értéket számoltunk, majd ezt követően a Bartlett-próbával azt vizsgáltuk, hogy a kiinduló változók között van-e korreláció, vagyis azok alkalmasak-e az elemzésre (SAJTOS és MITEV, 2007). 
Második lépésben a debreceni egyetemisták értékrendalapú szegmentációját végeztük el klaszteranalízis segítségével. A csoportosító eljárás során, szakmai szempontok alapján, a
LOHAS szegmenssel kapcsolatos faktorok esetében hierarchikus, míg a LOVOS szegmenssel kapcsolatos faktorok esetében k-means klaszterelemzési módszert használtunk.

\section{TÁBLÁZAT}

\section{A minta megoszlása a fontosabb háttérváltozók szerint (The Socio-demographic Background of the Sample)}

\begin{tabular}{|c|c|c|}
\hline \multirow[t]{2}{*}{$\begin{array}{l}\text { Megnevezés } \\
\text { (Criterion) }\end{array}$} & \multicolumn{2}{|c|}{$\begin{array}{l}\text { A minta } \\
\text { megoszlása } \\
\text { (Division of } \\
\text { the sample) }\end{array}$} \\
\hline & $\mathbf{N}$ & $\%$ \\
\hline \multicolumn{3}{|l|}{ Összes megkérdezett (Total number of respondents) } \\
\hline Összesen (Total) & 298 & 100,0 \\
\hline \multicolumn{3}{|l|}{ Nemek szerint (Gender) } \\
\hline Férfi (Men) & 141 & 47,3 \\
\hline Nö (Women) & 157 & 52,7 \\
\hline \multicolumn{3}{|l|}{ Lakóhely (Settlement) } \\
\hline 2 ezer fönél kisebb település (Settlement with less than 2 ooo residents) & 20 & 6,7 \\
\hline 2 ás 10 ezer fö közötti település (Town with between $2000-10$ ooo residents) & 41 & 13,8 \\
\hline 10 ezer fónél nagyobb város (Town with more than 10 ooo residents) & 46 & 15,4 \\
\hline Megyei jogú város (County town) & 170 & 57,0 \\
\hline Főváros (Capital city) & 20 & 6,7 \\
\hline \multicolumn{3}{|l|}{ Családi állapot (Family status) } \\
\hline Egyedülálló (Single) & 148 & 49,7 \\
\hline Társas kapcsolatban (In a relationship) & 149 & 50,3 \\
\hline \multicolumn{3}{|c|}{ Háztartás elsődleges élelmiszer beszerzője (Primary food purchaser of the household) } \\
\hline Igen (Yes) & 137 & 41,3 \\
\hline $\operatorname{Nem}(\mathrm{No})$ & 173 & 58,1 \\
\hline \multicolumn{3}{|c|}{ Internetezéssel átlagosan eltöltött idő naponta (Average daily time spent online) } \\
\hline$<30 \mathrm{~min}$ & 7 & 2,3 \\
\hline $30 \min -1 \mathrm{~h}$ & 20 & 6,7 \\
\hline $1-2 \mathrm{~h}$ & 94 & 31,5 \\
\hline $3-5 \mathrm{~h}$ & 129 & 43,3 \\
\hline $6-10 \mathrm{~h}$ & 45 & 15,1 \\
\hline $10 \mathrm{~h}<$ & 3 & 1,0 \\
\hline
\end{tabular}

Forrás (Source): Saját szerkesztés (Own compilation) 2017 


\section{EREDMÉNYEK ÉS ÉRTÉKELÉSÜK} - Results AND Discussion

\subsection{LOHAS és LOVOS értékek összehasonlítása - Comparison of the LOHAS and LOVOS Values}

Az irodalmi áttekintést követően szükségesnek tartottuk a két szegmens értékalapú összehasonlítását kapcsolódási pontok, illetve az eltérő értékek megállapítása céljából (1. ábra). A szekunder kutatás eredményeképpen a következő megállapításokat tettük. Mindkét csoport értékrendjéről elmondható, hogy elutasítják a materializmust, és hogy fontos számukra a fenntartható fejlődés mindhárom pillére, tehát a környezeti, a gazdasági és a társadalmi szempont is.

A két szegmens értékrendjében eltérést tapasztaltunk a fogyasztás csökkentésére való törekvéssel kapcsolatban, amely a LOVOS szegmens esetében dominánsabban jelenik meg. A függetlenség, mint érték és a vallási meggyőződés jelenléte is inkább ennek a csoportnak fontosabb. Ezzel szemben a LOHAS szegmensnél a hedonizmus és az individualizmus kerül előtérbe. A domináns értékek alapján megállapítható, hogy míg az önkéntes egyszerüsítőknél (LOVOS) háttérbe szorul az egyén szerepe és sokkal fontosabb a közösség, addig a LOHAS fogyasztóknál az individualitás kiemelkedő érték marad.

Materializmus elutasítása (Rejection of materialism); Fenntarthatóság

(Sustainability): társadalmi (Social), gazdasági (Economic), környezeti (Environmental)

\section{1. ÁBRA}

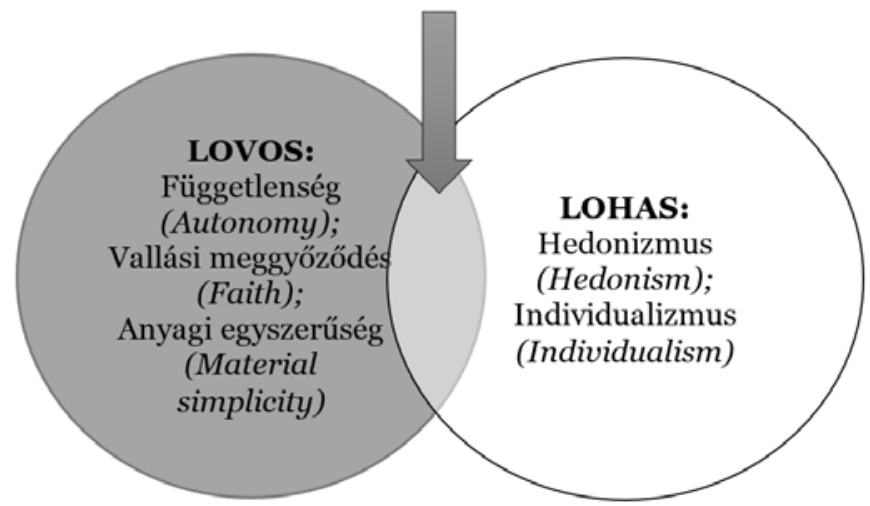

A LOVOS szegmens és a LOHAS szegmens összehasonlítása (Comparison of the LOHAS and LOVOS Segments)

Forrás (Source): Saját szerkesztés (Own compilation) 2017

\subsection{LOHAS értékek megjelenése} debreceni egyetemisták körében Appearance of LOHAS Values among the Students of the University of Debrecen

Ezt követően elvégeztük a primer kutatást a LOHAS értékek mentén debreceni egyetemisták körében. Az eredmények alapján megállapítottuk, SZAKÁLY és munkatársai (2015a) eredményeihez hasonlóan, hogy a debreceni egyetemisták számára az etikus értékek voltak azok, amelyeket a legkevésbé tartanak magukra nézve igaznak.
A mintaátlag értéke az etikus értékekre vonatkozó állításoknál igen alacsony (2,302,77), a szórás és a relatív szórás értéke viszont magas, amely a válaszok heterogenitását jelzi, vagyis a megkérdezettek véleménye megoszlik a kérdésben. Az egészség- és környezettudatos értékek megítélése viszont a leghomogénebb. Az állítások 3,5 feletti átlagot és viszonylag alacsony relatív szórást $(<30 \%)$ kaptak. Az autentikus és individualista értékek esetében kicsit heterogénebb képet kaptunk, azonban a válaszadók többsége inkább fontosnak ítéli meg ezeket az értékeket is (átlag>3,5) és a szórás is 
viszonylag elfogadható tartományban van.

$\mathrm{Az}$ eredmények alapján megállapítható (2a. és 2b. táblázat), hogy SZAKÁLY és munkatársai (2015b) kutatási eredményeihez hasonló képet kapunk a debreceni egyetemisták körében elvégzett megkérdezés során is. Különbségként említhető, hogy jelen tanulmányban az egészség- és környezettudatos értékek megítélése mentén nem húzódott olyan éles határvonal, mint ami SZAKÁLY és munkatársai (2015b) eredményeiből kiolvasható. A fent említett értékeket kevésbé tartották magukra nézve igaznak a debreceni egyetemisták, mint ami az országos megkérdezés során tapasztalható volt, azonban az individualista értékek fontosabbnak bizonyultak ebben az esetben.

2a. TÁBLÁZAT

TABLE 2 a

A LOHAS életstílussal kapcsolatos kérdések eredményei (Major Statistical Indicators of Agreement with the Statements of LOHAS Lifestyle According to Value Dimensions (N=298)

\author{
LOHAS állítások \\ (LOHAS statements)
}

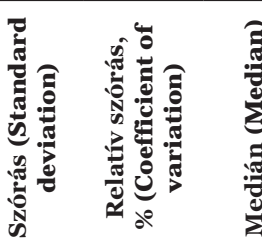

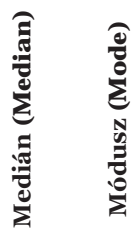

\begin{tabular}{|c|c|c|c|c|c|}
\hline \multicolumn{6}{|c|}{ Környezettudatos értékek (Environmental consciousness) } \\
\hline $\begin{array}{l}\text { Fontos, hogy a megvásárolt termék csomagolása újrahasznosítható legyen } \\
\text { (It is important that the packing of the product be recyclable) }\end{array}$ & 3,47 & 1,144 & 32,99 & 3 & 3 \\
\hline $\begin{array}{l}\text { Az energiatakarékos háztartási berendezések hozzájárulnak a fenntartható } \\
\text { fejlődéshez (Energy saving household gadgets contribute to sustainable } \\
\text { development) }\end{array}$ & 4,43 & 0,825 & 18,63 & 5 & 5 \\
\hline $\begin{array}{l}\text { Szükséges, hogy a gyerekek környezettudatos nevelésben részesüljenek } \\
\text { (Children should be educated to be environmentally conscious) }\end{array}$ & 4,64 & 0,652 & 14,04 & 5 & 5 \\
\hline \multicolumn{6}{|c|}{ Egészségtudatos értékek (Health consciousness) } \\
\hline $\begin{array}{l}\text { Előnyben részesítem az olyan élelmiszereket, melyek hozzájárulnak egész- } \\
\text { ségem megőrzéséhez (I prefer foods that contribute to staying healthy) }\end{array}$ & 4,27 & 0,861 & 20,18 & 4 & 5 \\
\hline $\begin{array}{l}\text { Napi étkezéseim tervezésekor figyelek arra, hogy megfelelő mennyiség- } \\
\text { ben hozzájussak a szervezetem számára nélkülözhetetlen tápanyagokhoz } \\
\text { (When I plan my daily meals I am careful that my body should get all the } \\
\text { necessary nutrients) }\end{array}$ & 3,57 & 1,065 & 29,79 & 4 & 4 \\
\hline $\begin{array}{l}\text { Az egészség megőrzéséhez nélkülözhetetlen a sport (Sport is essential to } \\
\text { stay healthy) }\end{array}$ & 4,41 & 0,85 & 19,27 & 5 & 5 \\
\hline $\begin{array}{l}\text { Rendszerint szezonális termékeket (pl. dinnye augusztusban) vásárolok } \\
\text { (I usually buy seasonal products (e.g. watermelon in August)) }\end{array}$ & 3,95 & 0,976 & 24,72 & 4 & 4 \\
\hline $\begin{array}{l}\text { Az élelmiszerekben megtalálható adalékanyagok károsítják az egészsége- } \\
\text { met (The additives in the food are harmful to my health) }\end{array}$ & 3,78 & 1,043 & 27,55 & 4 & 5 \\
\hline $\begin{array}{l}\text { Az egészséges táplálkozás szempontjából fontos, hogy az ember tisztában } \\
\text { legyen az élelmiszer-összetevők (pl. vitaminok, cukrok, telített zsírsavak) } \\
\text { élettani hatásaival (In terms of healthy eating, it is important to be aware } \\
\text { of the physiological effects of the food ingredients, e.g. vitamins, sugars, } \\
\text { saturated fat) }\end{array}$ & 4,26 & 0,935 & 21,94 & 5 & 5 \\
\hline \multicolumn{6}{|l|}{ Etikus értékek (Ethical values) } \\
\hline $\begin{array}{l}\text { Rendszerint adományokkal támogatom a civil szervezetek munkaját } \\
\text { (I regularly support the work of charity organizations with donations) }\end{array}$ & 2,30 & 1,232 & 53,70 & 2 & 1 \\
\hline Évente végzek karitatív tevékenységet (I do charity work annually) & 2,49 & 1,337 & 53,73 & 2 & 1 \\
\hline $\begin{array}{l}\text { Kedvezóbben ítélem meg azt a vállalatot, mely jótékonysági akciókat } \\
\text { támogat (I consider a company that donates to charities better) }\end{array}$ & 3,68 & 1,049 & 28,48 & 4 & 4 \\
\hline
\end{tabular}

Forrás (Source): Saját szerkesztés (Own compilation) 2017 
2b. TÁBLÁZAT

TABLE 2 b

A LOHAS életstílussal kapcsolatos kérdések eredményei (Major Statistical Indicators of Agreement with the Statements of LOHAS Lifestyle According to Value Dimensions)

$(\mathrm{N}=\mathbf{2 9 8})$

\begin{tabular}{|c|c|c|c|c|c|}
\hline $\begin{array}{l}\text { LOHAS állítások } \\
\text { (LOHAS statements) }\end{array}$ & 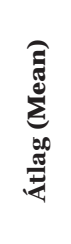 & 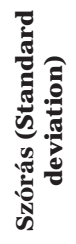 & 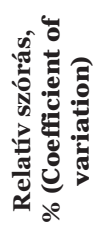 & 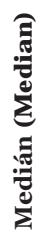 & 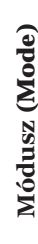 \\
\hline \multicolumn{6}{|c|}{ Etikus értékek (Ethical values) } \\
\hline $\begin{array}{l}\text { Kedvezóbben ítélem meg azt a vállalatot, mely kiemelten figyelmet fordít } \\
\text { a humánus munkakörülmények megteremtésére (I consider a company } \\
\text { that provides good working conditions for its employees better) }\end{array}$ & 3,95 & 1,017 & 25,77 & 4 & 4 \\
\hline $\begin{array}{l}\text { Kizárólag állatkísérletektól mentes termékeket vásárolok (I only buy } \\
\text { products that are free from animal testing) }\end{array}$ & 2,77 & 1,334 & 48,06 & 3 & 3 \\
\hline \multicolumn{6}{|c|}{ Autentikus értékek (Authentic values) } \\
\hline $\begin{array}{l}\text { Ha a helyi piacokon vásárolok élelmiszert, akkor azzal a magyar terme- } \\
\text { lóket támogatom (When I purchase food at the local markets, I support } \\
\text { Hungarian producers) }\end{array}$ & 4,11 & 1,007 & 24,49 & 5 & 5 \\
\hline $\begin{array}{l}\text { Fontos számomra a hagyományok tisztelete (Respect for traditions is } \\
\text { important to me) }\end{array}$ & 3,68 & 1,163 & 31,58 & 4 & 4 \\
\hline $\begin{array}{l}\text { Magyar termékek vásárlásával hozzájárulok az ország gazdasági fejlődésé- } \\
\text { hez (I contribute to the economic development of the country by buying } \\
\text { Hungarian products) }\end{array}$ & 4,03 & 0,935 & 23,19 & 4 & 4 \\
\hline $\begin{array}{l}\text { A termékeken szereplő védjegyek csökkentik bizonytalanságomat a vásár- } \\
\text { lás során (Trademarks on products reduce uncertainty during shopping) }\end{array}$ & 3,44 & 1,085 & 31,58 & 3 & 3 \\
\hline \multicolumn{6}{|c|}{ Individualista értékek (Individualism) } \\
\hline Fontos számomra a karrier (My career is important for me) & 4,10 & 0,954 & 23,27 & 5 & 5 \\
\hline A márkás termékeket részesítem előnyben (I prefer branded products) & 3,51 & 1,089 & 31,01 & 4 & 4 \\
\hline Az egyedi termékeket kedvelem (I prefer uniquely designed products) & 3,65 & ,998 & 27,35 & 4 & 4 \\
\hline $\begin{array}{l}\text { A legújabb divat szerint alakítom életvitelemet (I live according to the } \\
\text { latest fashion) }\end{array}$ & 2,42 & 1,095 & 45,29 & 2 & 2 \\
\hline $\begin{array}{l}\text { Olyan termékeket vásárolok, melyek tükrözik személyiségemet (I buy } \\
\text { products that reflect my personality) }\end{array}$ & 3,65 & 1,164 & 31,89 & 4 & 4 \\
\hline A magas minőségű termékeket kedvelem (I prefer high quality products) & 3,97 & 0,891 & 22,43 & 4 & 4 \\
\hline
\end{tabular}

Forrás (Source): Saját szerkesztés (Own compilation) 2017

A faktoranalízis eredményei - Results of Factor Analysis

Ezt követően a LOHAS szegmens értékeinek megjelenését faktorelemzés segítségével vizsgáltuk. Ennek során, a kérdőíven szereplő 24 fenntartható értékrendre vonatkozó állítás segítségével olyan értékeket azonosítottunk, amelyek a debreceni egyetemistákra kisebb-nagyobb mértékben jellemzőek.

Első lépésként a változók belső konzisztenciájának javítása érdekében 24 állítás közül öt kiiktatásra került (kritérium: faktorsúly> 0,50). Az így megmaradt 19 állítás 6 faktorba különül el (3a. és $3 b$. táblázat). 
3a. TÁBLÁZAT

A LOHAS állítások fő́csoportjainak elkülönülése (Factors Formed Based on LOHAS Lifestyle) $(\mathrm{N}=292)$

\section{LOHAS állítások (LOHAS statements)}

Az egészség megőrzéséhez nélkülözhetetlen a sport (Sport is essential to stay healthy)
0,72

Az egészséges táplálkozás szempontjából fontos, hogy az ember tisztában legyen az élelmiszer-összetevók (pl. vitaminok, cukrok, telített zsírsavak) élettani hatásaival (In terms of healthy eating, it is important to be aware of the physiological effects of the food ingredients, e.g. vitamins, sugars, saturated fat)

Előnyben részesítem az olyan élelmiszereket, melyek hozzájárulnak egészségem megőrzéséhez (I prefer foods that contribute to staying healthy)

Napi étkezéseim tervezésekor figyelek arra, hogy megfelelő menynyiségben hozzájussak a szervezetem számára nélkülözhetetlen tápanyagokhoz (When I plan my daily meals I am careful that my body should get all the necessary nutrients)

Kedvezőbben ítélem meg azt a vállalatot, mely kiemelten figyelmet fordít a humánus munkakörülmények megteremtésére (I consider a company that provides good working conditions for its employees better)

Szükséges, hogy a gyerekek környezettudatos nevelésben részesüljenek (Children should be educated to be environmentally conscious)

Az energiatakarékos háztartási berendezések hozzájárulnak a fenntartható fejlődéshez (Energy saving household gadgets contribute to sustainable development)

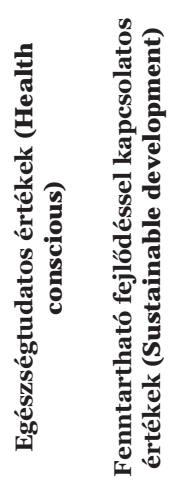

Kedvezőbben ítélem meg azt a vállalatot, mely jótékonysági akciókat támogat (I consider a company that donates to charities better)

Évente végzek karitatív tevékenységet (I do charity work annually)

Rendszerint adományokkal támogatom a civil szervezetek mun-

káját (I regularly support the work of charity organizations with donations)

Olyan termékeket vásárolok, melyek tükrözik személyiségemet (I buy products that reflect my personality)

0,68

Az egyedi termékeket kedvelem (I prefer uniquely designed products)

0,63 
A LOHAS állítások fócsoportjainak elkülönülése (Factors Formed Based on LOHAS Lifestyle) $(\mathrm{N}=292)$

\begin{tabular}{|c|c|c|c|c|c|c|}
\hline $\begin{array}{c}\text { LOHAS állítások } \\
\text { (LOHAS statements) }\end{array}$ & 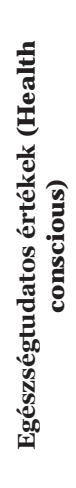 & 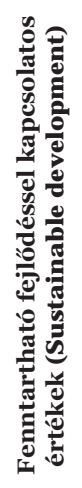 & 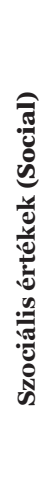 & 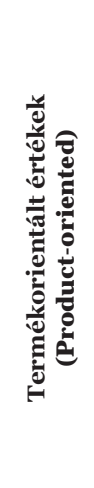 & 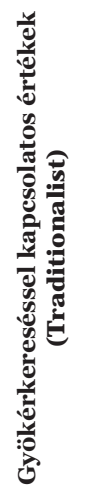 & 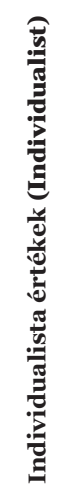 \\
\hline $\begin{array}{l}\text { Kizárólag állatkísérletektól mentes termékeket vásárolok (I only } \\
\text { buy products that are free from animal testing) }\end{array}$ & & & & 0,58 & & \\
\hline $\begin{array}{l}\text { Magyar termékek vásárlásával hozzájárulok az ország gazdasági } \\
\text { fejlődéséhez (I contribute to the economic development of the } \\
\text { country by buying Hungarian products) }\end{array}$ & & & & & 0,72 & \\
\hline $\begin{array}{l}\text { Fontos számomra a hagyományok tisztelete (Respect for } \\
\text { traditions is important to me) }\end{array}$ & & & & & 0,67 & \\
\hline $\begin{array}{l}\text { Rendszerint szezonális termékeket (pl. dinnye augusztusban) } \\
\text { vásárolok (I regularly support the work of charity organizations } \\
\text { with donations) }\end{array}$ & & & & & 0,58 & \\
\hline $\begin{array}{l}\text { A márkás termékeket részesítem előnyben (I prefer branded } \\
\text { products) }\end{array}$ & & & & & & 0,77 \\
\hline Fontos számomra a karrier (My career is important for me) & & & & & & 0,70 \\
\hline $\begin{array}{l}\text { A legújabb divat szerint alakítom életvitelemet (I live according to } \\
\text { the latest fashion) }\end{array}$ & & & & & & 0,51 \\
\hline
\end{tabular}

Extraction Method: Principal Component Analysis; Rotation Method: Varimax rotation with Kaiser Normalization; Rotation converged in 8 iterations; $\mathrm{KMO}=0,755$; Bartlett: (Approx. Chi Sq.) 994,888; (Sig.) 0;000; Total Variance Explained: 59,$275 ; \mathrm{N}=298$

Forrás (Source): Saját szerkesztés (Own compilation) 2017

Az első faktorban az egészségtudatossághoz kapcsolódó értékek jelennek meg, mint a sport, vagy a tudatos táplálkozás fontossága. A viszonylag magas faktorsúlyok arra utalnak, hogy az egészségtudatos értékek elkülönülnek a többitól és szerepük van a debreceni egyetemisták értékrendjének alakításában.

A második faktorba a fenntartható fejlődéssel kapcsolatos, elsősorban jövőorientált értékek tartoznak, mint a gyermekek környezettudatos nevelése, az energiatakarékos háztartási berendezések, illetve a vállalatok humánus és jótékonysági akciói.

A harmadik faktorban a szociális értékek dominálnak, úgymint a karitatív tevékenységek és a civilszervezetek támogatása. A magas faktorsúly arra utal, hogy ezek az értékek élesen elkülönülnek a többi értéktényezőtoól, illetve a magas faktorsúly fontosabb faktort jelez az illető indikátor alakulása szempontjából.

A negyedik faktorba olyan termékorientált értékek tömörültek, amelyek a termékek bizonyos tulajdonságaira helyezik a hangsúlyt. A csoportba tartozó fogyasztók olyan termékeket vásárolnak, amelyek egyediek, mentesek az állatkísérletektől vagy tükrözik a személyiségüket. A viszonylag alacsony faktorsúlyok azonban arra utalnak, hogy ezek az értékek kevésbé 
játszanak szerepet a debreceni egyetemisták értékítéletében.

Az ötödik faktor olyan értékek köré épül, amelyek a gyökerek keresésével kapcsolatosak. Ezek közül is a legfontosabbnak a hazai termékek vásárlása bizonyult, de megjelent a hagyományok tisztelete és a szezonális termékek vásárlására való törekvés is.

Végül a hatodik faktor az individualista értékeket jeleníti meg viszonylag magas faktorsúllyal, főleg a márkás termékek vásárlása vagy a karrierorientáltság esetében, amely arra utalhat, hogy ezek a tényezők nagymértékben alakítják az egyetemisták értékrendjét.

Összefoglalva megállapítható, hogy a debreceni egyetemisták körében is megjelentek a fenntartható fejlődéssel kapcsolatos értékek, még ha a faktorok átlagosan alacsonyabb faktorsúlyokkal is rendelkeztek, mint az
SZAKÁLY és munkatársai (2015b) országos felmérésének eredményeiben tapasztalható volt. Az eredmények alapján kijelenthetjük, hogy a debreceni egyetemisták számára az egészségtudatos és az individualista értékek a legfontosabbak.

\section{A szegmentálás eredményei - Results of Segmentation}

A faktoranalízis során megállapított értékek mentén második lépésben elvégeztük a debreceni egyetemisták értékrendalapú szegmentációját hierarchikus klaszterelemzési módszer alkalmazásával. A klaszterelemzési eljárás elvégzése után 4 klasztercsoportot tudtunk elkülöníteni (2. ábra) a LOHAS szegmens értékeire vonatkozóan.

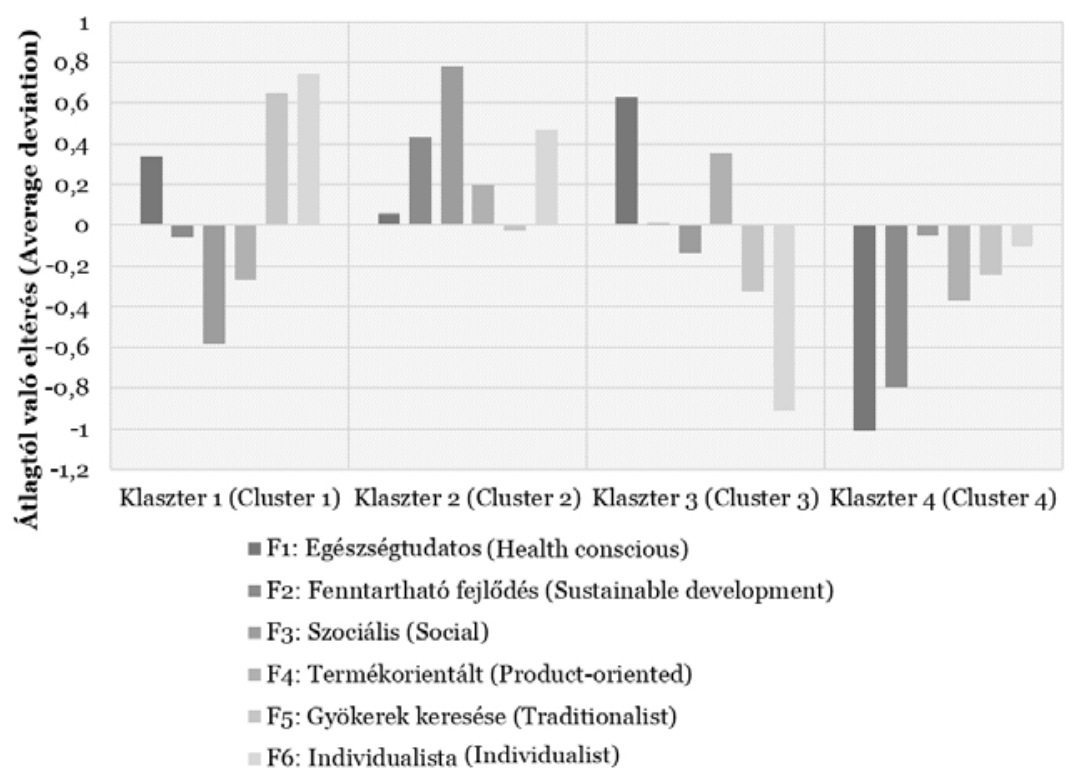

2. ÁBRA

A LOHAS szegmens klasztereinek és faktorainak viszonyulása

(Clusters and Factors of the LOHAS Segment) $(\mathrm{N}=\mathbf{2 1 5})$

Forrás (Source): Saját szerkesztés (Own compilation) 2017

Az első klaszter tagjai a „Hagyománytisztelő individualisták”, akik a teljes mintasokaság 20\%-át alkotják. Legfontosabbnak az individualista értékeket tartják, így fontos számukra a karrier és a divat, vásárlásnál pedig előnyben részesítik a márkás ruhákat. A többi csoport- hoz képest felülértékelik a hagyományokkal kapcsolatos értékeket, így a hazai termékek fogyasztását preferálják, fontos számukra a hagyományok tisztelete, emellett vásárlásuknál szem előtt tartják az idényjellegű termékek választását. A felsorolt értékcsoportok közül leg- 
inkább a szociális értékeket értékelik alul, így a civilszervezetek támogatását és az önkéntes munkát.

A klaszterben enyhén dominál a férfiak aránya (55,6\%), családi állapotukat tekintve többségben vannak az egyedülállók (61,1\%) és azok, akik nem tekinthetők a háztartás elsődleges élelmiszer-beszerzőinek (66,0\%).

Érdekes módon, a többi klaszterhez viszonyítva, itt a legalacsonyabb a felsőfokú diplomával rendelkezők aránya (20,4\%).

A második klaszter tagjai, az „Ambiciózus trendkövetők”, akik a mintán belül a második legnagyobb csoportot alkotják (25,1\%-a a teljes mintasokaságnak), illetve ez a csoport mutatja a legnagyobb elköteleződést a fenntartható életstílus iránt. Legfontosabbnak a szociális értékeket tarják, de az individualista és a fenntartható fejlődéssel kapcsolatos értékeket is felülprezentálják. Az utóbbi értékcsoport jellemzőiből fakadóan, fontos számukra a jövőorientáció, a gyermekek környezettudatos nevelése és az energiatakarékos berendezésekre való átállás. Pozitívan értékelik továbbá a vállalatok jótékonysági akcióit és humánus munkakörülmények megteremtésére vonatkozó törekvéseit. Kis mértékben a termékorientált értékek is megjelennek az értékrendszerükben, azonban közömbösek az egészségtudatossággal és a gyökerek keresésével kapcsolatos értékek iránt.

A szegmentumban a nók dominálnak (60,0\%). Családi állapotukat tekintve enyhén felülreprezentáltak a társas kapcsolatban élők (56,9\%) és azok, akik nem tekinthetők a háztartásuk elsődleges élelmiszer-beszerzőjének (56,9\%). Lakóhelyüket tekintve a válaszadók 47,7\%-a lakik megyei jogú városban, tehát feltételezhetjük, hogy a szegmens tagjainak több mint fele olyan debreceni egyetemista, akinek lakóhelye nem Debrecen.

Az „Egészségtudatosok” számára (19,5\%) legfontosabb értékként az egészség jelenik meg. Tudatosan figyelnek a megvásárolni kí- vánt termék összetevőire és törekednek egy olyan étrend kialakítására, amelyben minden szükséges tápanyag biztosítva van a szervezetük számára. Egyetértenek abban, hogy az egészség megőrzésében nélkülözhetetlen szerepet játszik a testmozgás. Az egészségtudatosság mellett felülértékelik a termékorientált értékeket is, vagyis törekednek olyan termékeket vásárolni, amelyek egyediek, tükrözik az értékrendjüket és a személyiségüket. Igyekeznek szem előtt tartani azt is, hogy a megvásárolt termék állatkísérletektől mentes legyen. A klaszter tagjai leginkább a márkás termékek vásárlását, a divat követését és a karrier fontosságát értékelik alul.

Az összes klaszterhez viszonyítva, ebben a szegmentumban a legnagyobb a nók aránya (64,9\%) és itt a legmagasabb a társas kapcsolatban élők száma is (59,6\%). Ez az egyetlen olyan szegmens, ahol többségben vannak azok, akik a háztartás elsődleges élelmiszer-beszerzőjének tekinthetők (54,4\%). Ennek alapján feltételezhetjük, hogy a klaszter tagjainak többsége már önálló háztartást vezet.

Lakóhely alapján itt a legmagasabb a debreceni lakosok aránya (70,2\%). Fontos megemlíteni, hogy a többi klaszterhez viszonyítva ebben a szegmensben rendelkeznek a legtöbben már valamilyen felsőfokú diplomával $(47,4 \%)$.

$\mathrm{Az}$ utolsó és egyben legnagyobb csoportot $(35,4 \%)$ a negyedik klaszter tagjai képviselik, ők a „Trendelutasító passzívak”. Jellemzően az összes értékcsoportot alulértékelik, a fenntartható és az individualista értékeket egyaránt. Leginkább az egészségtudatos, míg legkevésbé a szociális értékeket utasítják el.

A klaszterben enyhén dominálnak a férfiak (52,3\%), akiknek 50,0\%-a egyedülálló. Jellemzően nem ők tekinthetők a háztartás elsődleges élelmiszer-beszerzőinek (59,1\%). Lakóhelyüket tekintve itt a legalacsonyabb a debreceni lakosok aránya $(43,2 \%)$ és ennek a szegmentumnak a tagjai közül élnek legtöbben 10 ezer fő alatti településen (29,1\%). 


\subsection{LOVOS értékek megjelenése debreceni egyetemisták körében - Appearance of LOVOS Values among the Students of the University of Debrecen}

A LOHAS csoporthoz hasonlóan, a LOVOS szegmens esetében is megvizsgáltuk, hogy megjelennek-e az életstílusra jellemző értékek a debreceni egyetemisták körében. Tekintve, hogy a LOVOS fogyasztói csoporttal kapcsolatban mind a hazai, mind a nemzetközi kutatások kezdeti stádiumban vannak, ezért vizsgálatunk feltáró jellegünek tekinthető.

$\mathrm{Az}$ eredmények alapján megállapítható, hogy a LOVOS életstílussal kapcsolatos értéke- ket a válaszadók kevésbé tartották önmagukra nézve igaznak (4. táblázat) a LOHAS szegmens esetében tapasztaltakhoz képest. Az állítások többségében (4 állításban), alacsony a mintaátlag értéke $(<3,45)$, amihez magas relatív szórás érték tartozik (38,8\%), ezek alapján megállapíthatjuk, hogy a válaszok igen heterogének, így az átlag sem jellemzi jól az adatsort.

A legkisebb átlag értéket $(2,66)$ a spirituális (hittel kapcsolatos) állítás kapta, míg a legkedvezőbb megítélése a „Ha valami elromlik, először megpróbálom megjavítani/megjavíttatni, mielőtt újat vennék.” - állításnak volt (átlag: 4,32), amelyhez viszonylag alacsony relatív szórás érték is tartozott (20,2\%).

TABLE 4

A LOVOS életstílussal kapcsolatos kérdések eredményei (Major Statistical Indicators of Agreement with Statements of LOVOS) $(\mathrm{N}=\mathbf{2 9 8})$

(LOVO)

焉

\begin{tabular}{|c|c|c|c|c|c|}
\hline $\begin{array}{l}\text { Tudatosan igyekszem csökkenteni a fogyasztásomat, csak olyan termé- } \\
\text { keket vásárolok, amelyekre valóban szükségem van (I try to reduce my } \\
\text { consumption in a self-directed way and I only buy products which I } \\
\text { really need) }\end{array}$ & 3,63 & 1,033 & 28,47 & 4 & 4 \\
\hline $\begin{array}{l}\text { Vásárlás előtt általában listát írok azokról a termékekról, amit meg } \\
\text { szeretnék vásárolni, törekszem kerülni az impulzusvásárlást (Before I go } \\
\text { shopping, I write a list about the products that I want to buy. I try to } \\
\text { avoid impulse purchase) }\end{array}$ & 3,45 & 1,339 & 38,76 & 4 & 5 \\
\hline $\begin{array}{l}\text { A tömegközlekedést részesítem előnyben, hogy ezzel is óvjam a környeze- } \\
\text { temet (I prefer the public transport to protect my environment) }\end{array}$ & 2,99 & 1,417 & 47,44 & 3 & 3 \\
\hline $\begin{array}{l}\text { Ha valami elromlik, először megpróbálom megjavítani, mielőtt újat ven- } \\
\text { nék (If something breaks down, I try to fix it first before I buy a new one) }\end{array}$ & 4,32 & 0,872 & 20,17 & 5 & 5 \\
\hline $\begin{array}{l}\text { Az anyagi javak birtoklásával szemben számomra fontosabbak a spirituális } \\
\text { értékek, mint például a hit (Spiritual values like faith are more important } \\
\text { for me than possessing material goods) }\end{array}$ & 2,66 & 1,252 & 47,09 & 3 & 3 \\
\hline $\begin{array}{l}\text { Fontos számomra, hogy olyan közösségeknek legyek a tagja, legyen ez vir- } \\
\text { tuális vagy valós, amelyeket hasonló értékrendú emberek alkotnak (I try } \\
\text { to reduce my consumption in a self-directed way and I only buy products } \\
\text { which I really need) }\end{array}$ & 3,73 & 1,103 & 29,54 & 4 & 4 \\
\hline
\end{tabular}

Forrás (Source): Saját szerkesztés (Own compilation) 2017 
A faktoranalízis eredményei - Results of Factor Analysis

Ezt követően a LOVOS szegmens értékeivel kapcsolatban is elvégeztük a faktoranalízist, amelynek során a változók belső konzisztenciájának javítása érdekében a vizsgált 7 állítás közül 1 kiiktatásra került (kritérium: faktorsúly>0,50). A megtartott állítások segítségével három értékcsoportot tudtunk azonosítani, amelyet az 5. táblázat szemléltet.

Az első faktorban a tudatos csökkentéssel kapcsolatos érték jelent meg, amely elutasítja a sokszor túlfogyasztást okozó impulzusvásárlást. Az elromlott eszközök megjavítására való törekvés szintén ott van az értékek között. A faktoron belül a faktorsúlyok viszonylag magasak, amelyek alapján azt mondhatjuk, hogy ez az értékdimenzió jelentős hatással van a debreceni egyetemisták értékrendjére.

A második faktorban a közösségi léttel kapcsolatos értékek jelentek meg. A magas faktorsúly arra utal, hogy a közösségbe való tartozás értéke fontos kritérium az egyetemisták számára.

Az utolsó, harmadik faktor a környezettudatos értékeket jeleníti meg, így a tömegközlekedés preferálását és a fogyasztás tudatos csökkentésére való törekvést. Az előbbi állítás kapta a legmagasabb faktorsúlyt az összes állítás közül, az utóbbi (tudatos fogyasztáscsökkentéssel kapcsolatos) pedig a legalacsonyabbat.
LOVOS állítások

(LOVOS statements)

\begin{tabular}{ccc}
\hline LOVOS állítások \\
(LOVOS statements)
\end{tabular}

Ha valami elromlik, elöször megpróbálom megjavítani, mielött újat vennék (If something breaks down, I try to fix it first before I buy a new one)

Vásárlás előtt listát írok azokról a termékekről, amit meg szeretnék vásárolni, törekszem

kerülni az impulzusvásárlást (Before I go shopping, I write a list about the products that I want to buy, I try to avoid impulse purchase)
$0,75^{8}$

0,727

Az anyagi javak birtoklásával szemben számomra fontosabbak a spirituális értékek, mint például a hit (Spiritual values like faith are more important for me than possessing material goods)

Fontos számomra, hogy olyan közösségeknek legyek a tagja, ahol hasonló értékrendű emberekkel találkozhatom (It is important for me to be a member of a community where I can meet people with similar values as mine)

A tömegközlekedést részesítem előnyben, hogy ezzel is óvjam a környezetemet (I prefer the public transport to protect my environment)

Tudatosan igyekszem csökkenteni a fogyasztásomat, csak olyan termékeket vásárolok, amelyekre valóban szükségem van (I try to reduce my consumption in a self-directed way and I only buy products which I really need)

0,825

0,811

Extraction Method: Principal Component Analysis; Rotation Method: Varimax rotation with Kaiser Normalization; Rotation converged in 3 iterations; $\mathrm{KMO}=0,629$; Bartlett: (Approx. Chi Sq.) 152,712; (Sig.) 0;0oo; Total Variance Explained: 65,872; N=298

Forrás (Source): Saját szerkesztés (Own compilation) 2017 
A szegmentálás eredményei - Results of Segmentation

Ebben az esetben is elvégeztük a válaszadók ér- tékrendalapú szegmentációját k-means klaszterezési eljárást alkalmazva. A csoportosító eljárás eredményeképpen (3. ábra) szintén 4 életstílus csoportot tudtunk elkülöníteni.

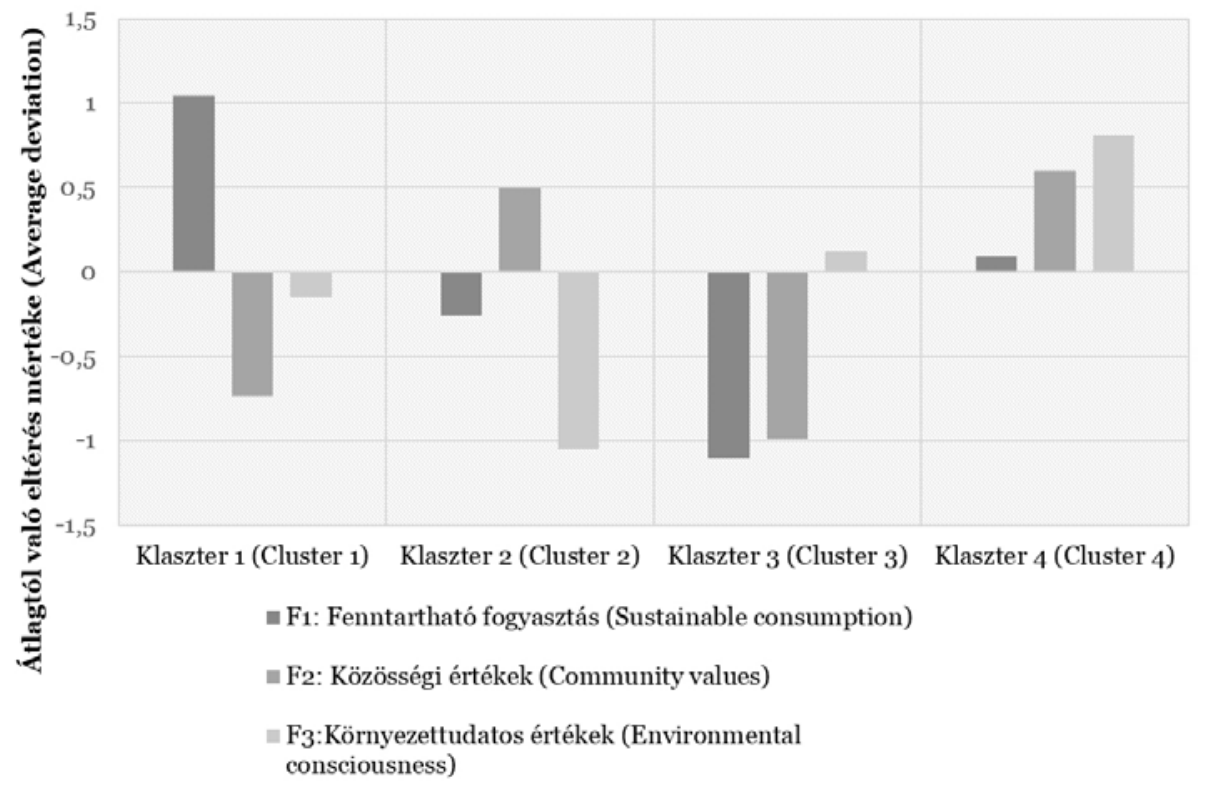

3. ÁBRA consciousness)

\section{A LOVOS szegmens klasztereinek és faktorainak viszonyulása}

(Clusters and Factors of the LOVOS Segment) $(\mathrm{N}=\mathbf{2 7 5})$

Forrás (Source): Saját szerkesztés (Own compilation) 2017

A „Tudatos csökkentők” esetében (mintasokaság 21,8\%-a) láthatjuk, hogy a csoport tagjaira jellemzőek a tudatos csökkentéssel kapcsolatos értékek, az impulzusvásárlás kerülése, illetve az, hogy ha valami elromlik, akkor inkább megpróbálják először megjavítani, mielőtt újat vennének. A csoport azonban a közösségi és a környezettudatos értékeket jellemzően elutasítja.

A szegmensben a férfiak és nők aránya pontosan 50-50\%. Többségben vannak a társas kapcsolatban élők (60\%), továbbá enyhén felülprezentáltak azok, akik a háztartásuk elsődleges élelmiszer beszerzői (53,3\%). A többi klaszterhez viszonyítva ebben a klaszterben a legtöbb a debreceni lakos (60,0\%).

A második klaszter, vagyis a „Szociálisan aktívak" (25,8\%) számára a közösségi értékek a legfontosabbak. Kiemelt értékként jelenik meg a csoporthoz tartozás (akár valós, akár virtuális), de fontosak számukra a spirituális értékek is. Karakteresen elutasítják a környezettudatos értékeket, vagyis a fogyasztás tudatos csökkentését és a tömegközlekedés preferálását.

A klaszter tagjai között a nők dominálnak (54,9\%), enyhe többségben vannak a társas kapcsolatban élők (52,1\%), akik azonban nem tekinthetők háztartásuk elsődleges élelmiszerbeszerzőjének (57,7\%). A szegmens tagjai között enyhe túlsúlyban vannak a debreceni lakosok (57,7\%) és itt a legmagasabb a diplomával rendelkezők aránya a többi szegmenshez viszonyítva $(36,6 \%)$

A harmadik klaszter, a „Közömbösek” (17,8\%) körében egyik értékcsoport sem érvényesül igazán, egyedül a környezettudatos értékek iránt voltak közömbösek, míg a többit elutasították. Ennek alapján megállapíthatjuk, hogy a fenntartható életmód iránt alacsony az elkötelezettségük, azonban fontos megemlíteni, hogy ez a klaszter alkotja a legkisebb csoportot a mintán belül. 
A klaszter tagjai között (ebben a szegmensben egyedül) túlsúlyban vannak a férfiak (53,1\%), valamint ebben a szegmensben a legmagasabb az egyedülállók aránya (67,3\%), továbbá itt vannak leginkább túlsúlyban azok, akik nem tekinthetőek a háztartás elsődleges élelmiszer-beszerzőjének. A szegmens tagjai jellemzően debreceni lakosok (59,2\%).

Végül a negyedik klaszter, a „Tudatos egyszerüsítők” (34,6\%) esetében tapasztalhatjuk a legnagyobb elköteleződést a LOVOS életstílus iránt. Mindhárom értékcsoport megjelenik náluk, amelyek közül a közösségi és a környezettudatos értékeket reprezentálják felül.

A klaszter tagjai között enyhén dominálnak a nők (53,7\%), illetve túlsúlyban vannak a társas kapcsolatban élők (53,7\%), többségük azonban mégsem tekinthető a háztartás elsődleges élelmiszer-beszerzőjének (57,9\%). Mindössze a szegmens tagjainak fele (50,5\%) debreceni lakos, így ebben a csoportban a legnagyobb a 10 ezer fó alatti település és a fóváros lakóinak a száma.

\section{KÖVETKEZTÉSEK ÉS}

\section{JAVASLATOK - CONCLUSIONS AND}

\section{PROPOSALS}

A kutatásunk során célunk volt a fenntartható fogyasztás iránt elkötelezett fogyasztói szegmensek (LOHAS és LOVOS) jellemző értékrendjének feltárása, vásárlási magatartásuk meghatározása és megjelenésük vizsgálata, elsősorban debreceni egyetemisták körében.

Első lépésként elvégeztük a két szegmens értékalapú összehasonlítását kapcsolódási pontok, illetve az eltérő értékek megállapítása céljából. Közös értékként a materializmus elutasítását és a fenntarthatóság megjelenését állapítottuk meg (társadalmi, gazdasági és környezeti szinten egyaránt). Különbség a két szegmens értékrendje között, hogy a LOVOS életstílus képviselőinél erőteljesebben jelenik meg a fogyasztás csökkentésére való törekvés, a függetlenség fontossága és a vallási meggyőződés. Ezzel szemben a LOHAS szegmensnél inkább a hedonizmus és az individualizmus kerül előtérbe. Ezek alapján megállapítható, hogy míg az önkéntes egyszerüsítőknél (LOVOS) háttérbe szorul az egyén és sokkal fontosabb a közösség, addig a LOHAS fogyasztóknál az egyén szerepe kiemelkedően fontos marad.

Második lépésként elvégeztünk egy kérdőíves megkérdezést ( $\mathrm{N}=298$ fó) debreceni egyetemisták körében, amelyet 2017 áprilisában bonyolítottunk le. A kérdőív első 24 kérdése vonatkozott a LOHAS életstílusra.

A kutatás feltáró jellegű volt, az eredményekből létrehozott 6 faktor alapján 4 fogyasztói klasztert határoztunk meg (Hagyománytisztelő individualisták, Ambiciózus trendkövetők, Egészségtudatosok, Trendelutasító passzívak).

A 4 klaszter közül háromban (Hagyománytisztelő individualisták, Ambiciózus trendkövetők, Egészségtudatosok) különböző mértékben, de megjelentek a LOHAS életstílussal kapcsolatban megfogalmazott értékek. Az Ambiciózus trendkövetők (a mintasokaság 25,1\%-a) esetében pedig a kutatás során megfogalmazott 6 faktorérték (egészségtudatos, fenntartható fejlődéssel kapcsolatos, szociális, termékorientált, individualista, gyökerek keresésével kapcsolatos értékek) egy kivételével mind megjelent. Egyedül a gyökerek keresésével kapcsolatos értéket utasították el kis mértékben, míg legfontosabbnak a szociális értékeket tartották, de az individualista és a fenntartható fejlődéssel kapcsolatos értékeket is felülprezentálták. Habár ennek alapján az Ambiciózus trendkövetők nem tekinthetők teljes egészében a LOHAS értékek iránt elkötelezett fogyasztói csoportnak, ennek a klaszternek a tagjai körvonalazzák leginkább a LOHAS fogyasztók életstílusának jellemzőit.

A LOVOS szegmens vizsgálatánál szintén kérdőíves megkérdezést alkalmaztunk, 7 állítás segítségével próbáltuk feltárni a LOVOS szegmens értékeinek megjelenését a debreceni egyetemisták körében. A LOVOS szegmens klaszterei közül a Tudatos egyszerüsítők (mintasokaság 34,6\%-a), képviselték leginkább az életstílusra jellemző értékeket.

Mivel jelen kutatásunk feltáró jellegű volt, ezért a témával kapcsolatban a jövőben vizsgálatainkat kiterjesztjük a teljes felnőtt lakosságra (reprezentatív leíró jellegű kutatás), egyrészt a két szegmens közötti kapcsolódási pontokra, másrészt a LOVOS értékek bizonyítására vonatkozóan. 


\section{6. ÖSSZEFOGLALÁS - SUMMARY}

Kutatásunk célja a fenntartható értékrend megjelenésének vizsgálata volt debreceni egyetemisták körében. Első lépésként célunk volt feltárni a LOHAS és a LOVOS fogyasztói csoportok értékeit és vizsgálni a két szegmens kapcsolatrendszerét. Ezt követően elemeztük az értékek megjelenését debreceni egyetemisták körében faktoranalízis segítségével. Majd k-means és hiearchikus klaszterezési eljárást alkalmazva az egyetemisták értékrendalapú életstílus-szegmentációját végeztük el mindkét szegmens esetében külön-külön.

Kutatásunk legfontosabb eredményeinek a következők tekinthetők. A LOHAS és LOVOS szegmens között bár több közös érték felfedezhető, azonban mégis két jól elkülöníthető csoportot alkotnak. A fenntarthatóság irányába mutató, ezen belül is a LOHAS életstílus jellemzői megjelentek a debreceni egyetemisták értékrendjében is. Az Ambiciózus trendkövetők csoportja (mintasokaság 25,1\%-a) nem tekinthető teljes egészében a LOHAS értékek iránt elkötelezett fogyasztói csoportnak, azonban a klaszter tagjai körvonalazzák leginkább a LOHAS fogyasztók életstílusának jellemzőit.

A LOVOS életstílus jellemzői szintén megjelentek a kutatás alapján a debreceni egyetemisták értékrendjében. A Tudatos egyszerüsítők (a mintasokaság 34,6\%-a) esetében tapasztalhatjuk a legnagyobb elköteleződést a LOVOS értékek irányában, náluk mindhárom, a szegmenssel kapcsolatban megfogalmazott értékcsoport jelen van.

\section{KöSZÖNETNYILVÁNÍTÁS - ACKNOWLEDGEMENT}

A publikáció elkészítését a EFOP-3.6.2-162017-00003 számú projekt támogatta. A projekt az Európai Unió támogatásával, az Európai Szociális Alap társfinanszírozásával valósult meg.
IRODALOMJEGYZÉK - REFERENCES

Ballantine, P. W. - Creery, S.: The Consumption and Disposition Behaviour of Voluntary Simplifiers. Journal of Consumer Behaviour. 2009. 9 45-56. https://doi.org/10.1002/cb.302

Elgin, D. - Mitchell, A.: Voluntary Simplicity. Planning Review. 1977. 5 (6) 13-15. https://doi.org/10.1108/ebo53820

Etzion, A.: Voluntary Simplicity: Characterization, Select Psychological Implications and Societal Consequences. Essays in Socio-Economics. Studies in Economic Ethics and Philosophy. 1999. 1-26. https://doi.org/10.1007/978-3-66203900-7_1

Fehér, A. - Soós, M. - Szakály, Z.: $\mathrm{Az}$ élelmiszer-fogyasztói magatartás vizsgálata online környezetben: létezik-e hazánkban digitális élelmiszerfogyasztó? Táplálkozásmarketing. 2014. 1 (1-2) 2938. https://doi.org/10.20494/TM/1/1-2/3

Fehér, A.: Az online fogyasztói magatartás vizsgálata az élelmiszeriparban. Doktori értekezés. Debreceni Egyetem. Debrecen, 2016. 1-200.

Field, A.: Discovering Statistics Using IBM SPSS Statistics. SAGE, 2013.

Gliem, J. A.: Calculating, Interpreting, and Reporting Cronbach's Alpha Reliability Coefficient for Likert-Type Scales, Presented the Midwest Research-toPractice Conference in Adult. The Ohio State University, Colombus, 2003. 82-88.

Gregg, R. B.: The Value of Voluntary Simplicity. In: Voluntary Simplicity, Responding to Consumer Culture (Szerk. Doherty, D. - Etzioni, A.). Rowman \& Littlefield Publihers, INC. New York, 2003. 131-144.

Hofmeister-Tóth, Á.: Fogyasztói értékek, trendek és magatartás. Vezetéstudomány. 2016. 47 (4) 26-29. 
Kocsis, T.: A materializmustól a teljes emberig. Kovász. 2001. (3-4) 101-136.

Lázár, E.: Kutatásmódszertanagyakorlatban az Spss program használatával. Scientia Kiadó, Kolozsvár, 2009. 164.

Mitev, A. - Horváth, D.: A posztmodern marketing rózsaszirmai. Management Review. 2008. 39 (9) 4-18.

Peyer, M. - Balderjahn, I. - Seegebarth, B. - Klemm, A.: The Role of Sustainability in Profiling Voluntary Simplifiers. Journal of Business Research. 2017. 70 (Jan) 37-43. https://doi. org/10.1016/j.jbusres.2016.07.008

Rácz, G.: $A z$ értékek változásának és a fenntartható fejlődés trendjének hatása a hazai élelmiszerfogyasztásra. Szent István Egyetem. Doktori értekezés. Gödöllő, 2013. 1-337.

Rich, S. A. - Hanna, S. - Wright, B. J.: Simply Satisfied: The Role of Psychological Need Satisfaction in the Life Satisfaction of Voluntary Simplifiers. Journal of Happiness Studies. 2017. 18 (1) 89-105. https://doi.org/10.1007/s10902-0169718-0

Sajtos, L. - Mitev, A.: SPSS Kutatási és Adatelemzési Kézikönyv. Budapest, 2007. 245-282.

Simai, M.: A fenntartható fejlődés három pillére és a globális kormányzás társadalmi háttére. Stratégiák, nemzeti környezetpolitikák és nemzetközi szervezetek. Közgazdaság. 2016. (1) 5-22.
Szakály, Z. - Pető, K. - Popp, J. Jasák, H.: A fenntartható fogyasztás iránt elkötelezett fogyasztói csoport, a LOHAS szegmens jellemzői. Táplálkozásmarketing. 2015a. 2 (1) 3-10. https://doi.org/10.20494/TM/2/1/2

Szakály, Z. - Pető, K. - Popp, J. - Jasák, H.: A LOHAS szegmens mérete és jellemzői Magyarországon. Táplálkozásmarketing. 2015b. 2 (1) 11-30. https://doi.org/ 10.20494/TM/2/1/1

Szakály, Z - Popp, J. - Kontor, E. Kovács, S. - Pető, K. - Jasák, H.: Attitudes of the Lifestyle of Health and Sustainability Segment in Hungary. Sustainability. 2017. 9 (10) 1763. https:// doi.org/10.3390/su9101763

Torda, T.: A tudatos fogyasztó, mint jövőbeli potenciális üzleti partner. Vállalkozásfejlesztés a XXI. században. Budapest, 391-412.

Törőcsik, M.: A tudatos fogyasztást és az egészséget preferáló új fogyasztói trendcsoport, a LOHAS Csoport megjelenése Magyarországon. Élelmiszer, Táplálkozás és Marketing. 2007.4 (1) 4145.

Törőcsik, M.: A fogyasztói magatartás új tendenciái. Vezetéstudomány. 2016. 47 (4) $19-25$.

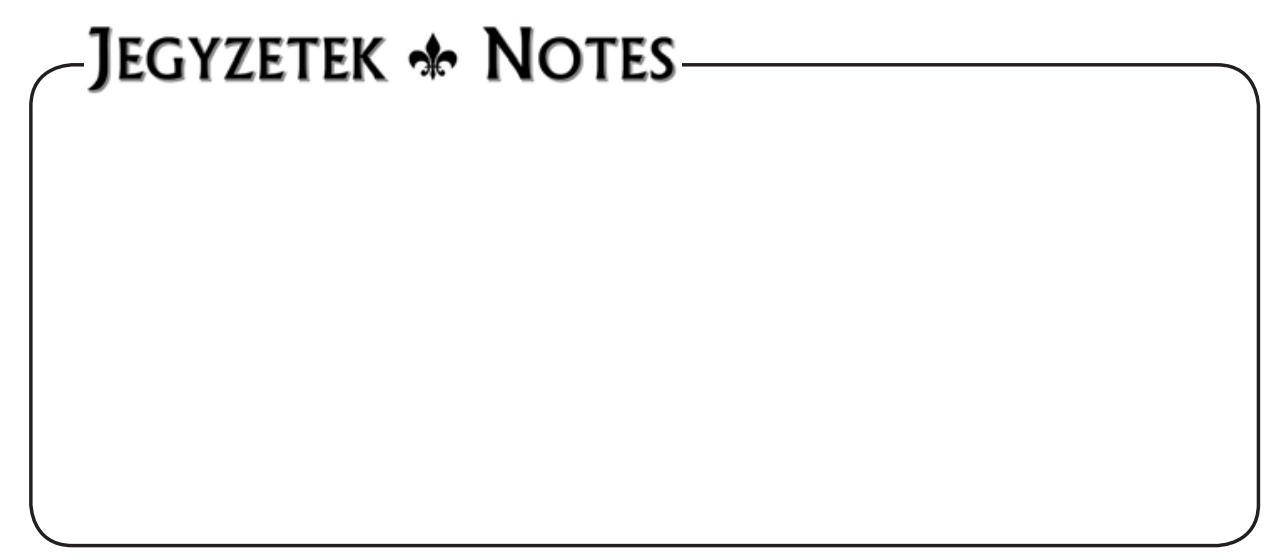

